\title{
Relationship of Fluoride Content with Physico-Chemical and Chemical Properties of Soil
}

\author{
Vijaya Lakshmi D, ${ }^{1}$ Jeevan Rao K, ${ }^{2}$ Ramprakash $\mathrm{T},{ }^{3}$ and Reddy A.P.K. ${ }^{4}$ \\ ${ }^{1}$ Krishi Vigyan Kendra, PJTSAU, Rudrur, Nizamabad, Telangana State, India \\ ${ }^{2}$ College of Agriculture, PJTSAU, Rajendranagar, Hyderabad, Telangana State, India \\ ${ }^{3}$ AICRP on Weed Control, PJTSAU, Rajendranagar, Hyderabad, Telangana State, India \\ ${ }^{4}$ Farmers Cal Centre, ANGRAU, Hyderabad, Telangana State, India
}

\begin{abstract}
This paper analyses fluoride content in 82 soil samples and correlated with physico-chemical and chemical properties of soil. The results indicated that, available $F$ concentration in soils positively correlated with $\mathrm{pH}$ and total $\mathrm{F}$ content of the soil whereas the correlation coefficient between available $F$ and EC was negative. The relationship between fluoride and CEC, fluoride and $\mathrm{P}_{2} \mathrm{O}_{5}$ was negative whereas the correlation coefficient between fluoride and other ions is very poor during both seasons. Increasing fluoride content in soil decreases the available $\mathrm{P}_{2} \mathrm{O}_{5}$ content of the soil. The reduction of $\mathrm{P}_{2} \mathrm{O}_{5}$ content in soil due to $\mathrm{F}$ addition can be attributed to formation of insoluble phosphorus compounds in the soils. Fluoride is negatively correlated with clay percent of soils and positively correlated with sand percent of soils during both seasons but no significant correlation was observed. Clay, soil $\mathrm{pH}$ and $\mathrm{P}_{2} \mathrm{O}_{5}$ in soil control fluoride content in the soil solution. Soil with high $\mathrm{pH}$ and low clay and $\mathrm{P}_{2} \mathrm{O}_{5}$ favours greater solubilization of the fluoride bearing minerals leads to leaching of fluoride which results increase in the concentration of soil fluoride.
\end{abstract}

Keywords: Nalgonda district, fluoride, soil, Physico-chemical and chemical properties.

\section{Introduction}

The mobility of fluoride in soils depends on a number of factors, including the initial fluoride concentration, solubility of mineral phases, type of soil, $\mathrm{pH}$ values in the soil and other dissolved components in the soil solution.

These factors determine whether or not fluorideis precipitated, sorbs to mineral surfaces or stays in solu tion either as a free or complexes species. The study and monitoring of fluorine and fluorides has been of interest to scientists for a long time. This is because of the reactivity and ready availability of fluorine in many forms. The main natural source of inorganic fluorides in soil is the parent rock. It is the $13^{\text {th }}$ most abundant element of the earth's crust representing about $0.3 \mathrm{~g} \mathrm{~kg}^{-1}$. It occurs naturally in the combined state as fluorite (fluorospar), apatite, fluorapatite, topaz and cryolite (Rakshit, 2004).

The world average of fluoride concentration in granitic rocks was found to be $810 \mathrm{ppm}$ (Wedepohl 1969), while fluoride content of granitic rocks from Nalgonda district was found to be in the range of 325 to $3,200 \mathrm{ppm}$, with a mean of 1,440 ppm (Rao et al., 1993). Thus, the granitic rocks of Nalgonda possess the highest fluoride content than in any other parts of the world. Assessment of the granite gneisses from Nalgonda showed the presence of fluoride containing minerals such as fluorite $(0-3.3 \%)$, biotite $(0.1-1.7 \%)$, and hornblende (0.1-1.1\%) (Reddy et al., 2009). The clay content and $\mathrm{pH}$ of soil are primarily responsible for the origin and/or retention of F in soils. F in soil is primarily associated with the soil colloid or clay (Omueti and Jones, 1977). Correlation coefficients between fluorine content (total and available) and some important chemical and physical soil properties were studied.

\section{Materials And Methods}

A survey was carried out in Ramannapet, Narkatpalli and Aatmakoor mandals of Nalgonda district by covering all the villages, with a view to assess characterization of soil during two seasons i.e. kharif (2012) and rabi (2012-13). As per the objectives laid down for this study, from each village one soil sample was collected with the help of a handheld Global Positioning System (GPS). Totally 82 benchmark sites were fixed depending on the number of villages in three mandals for collection of soil samples at each site in each season. The samples were collected at $0-15 \mathrm{~cm}$ depth by adopting the standard procedures of soil sample collection. The collected soil samples were air dried, gently pounded in wooden mortar and pestle, sieved (2 mm sieve) and preserved in polythene bags for further analysis.

The samples were analyzed for $\mathrm{pH}$, EC and $\mathrm{OC}$ as per the standard procedure outlined by Jackson (1973). Available nitrogen was estimated by alkaline potassium permanganate method (Subbaiah and Asija, 1956). Available phosphorus content was estimated by Olsen's reagent as described by Olsen et al. (1956) and determined by ascorbic acid method (Watanabe and Olsen, 1965), available potassium was extracted by using 
neutral normal ammonium acetate (Jackson, 1973) and determined by flame photometer. Available micronutrients (DTPA extractable) $\mathrm{Fe}, \mathrm{Mn}, \mathrm{Cu}$ and $\mathrm{Zn}$ were analyzed by DTPA method using atomic absorption spectrophotometer (Lindsay and Norvell, 1978). The total fluoride was analyzed by $\mathrm{NaOH}$ fusion technique using Fluoride Ion Selective Electrode (FISE) method given by McQuaker and Gurney (1977). Available fluoride in soil samples analyzed by Potentiometric method (McQuaker and Gurney, 1977).

\subsection{Available Fluoride and Total Fluoride}

\section{Results And Discussion}

The mean values of available F present in the soil samples of Ramannapet, Narkatpalli and Aatmakoor mandals were $1.17,1.18$ and $1.04 \mathrm{mg} \mathrm{kg}^{-1}$, respectively in kharif season and $1.41,1.66$ and $1.54 \mathrm{mg} \mathrm{kg}^{-1}$, respectively in rabi season (Table 1 and 2). All the values obtained were well within the desirable range of 2.57 to $16.44 \mathrm{mg} \mathrm{kg}^{-1}$ soil F. All the values obtained are well within the range of 2.57 to $16.44 \mathrm{mg} \mathrm{kg}^{-1}$ soil leachable F stipulated by WHO, 1984. The soil leachable F is the main factor which determines the availability of $\mathrm{F}$ for plant absorption. Similarly, F content in soil between 0.02 and $1.00 \mathrm{mg} \mathrm{kg}^{-1}$ as reported by Davidson (1983) and between 0.075 and $0.200 \mathrm{mg} \mathrm{kg}^{-1}$ as obtained by Okibe et al. (2010).

The average content of total F distributed in soils of Ramannapet, Narkatpalli and Aatmakoor mandals were 279,310 and $291 \mathrm{mg} \mathrm{kg}^{-1}$, respectively in kharif season and 289,338 and $314 \mathrm{mg} \mathrm{kg}^{-1}$, respectively in rabi season. Nearly $6 \%$ of soil samples in both kharif and rabi seasons recorded higher total F content than the usual range and remaining samples were within its normal range. Total $\mathrm{F}$ of normal soils is usually in the range from 150 to $400 \mathrm{mg} \mathrm{kg}^{-1}$ as prescribed by Newman (1984). Nearly $6 \%$ of soil samples recorded higher than the usual range and remaining $94 \%$ of samples were within its normal range indicates its geo-chemical origin without any form of artificial contamination. So, a danger from $\mathrm{F}$ accumulation in plants and its toxicity to human and animals are not to be expected. The results are in conformity with the findings of Jakovljevic et al., 2002.

The percentage of available $\mathrm{F}$ from its total $\mathrm{F}$ content ranges from 0.10 to 0.82 . The available $\mathrm{F}$ content was very low ( 0.26 to $2.64 \mathrm{mg} \mathrm{kg}^{-1}$ soil), being less than $1 \%$ from its total amount, so it could be concluded that there was no danger from $\mathrm{F}$ accumulation in the plants. The content of available $\mathrm{F}$ in the soil samples is very low indicating that major part of deposited $\mathrm{F}$ had transformed itself in to insoluble compounds like $\mathrm{CaF}_{2}$ (Blagojevic et al. 2002). These results are in conformation with the findings of Jakovljevic et al. (2002). Unfortunately there is no Indian standard available prescribing a limit to the $\mathrm{F}$ in soil and biological tissue. Although around $95 \%$ of the $\mathrm{F}$ deposited in soil surface is not available for plant uptake because of its conversion to unavailable form.

\subsection{Physico-Chemical and Chemical Properties of Soil}

The results indicated that the soils are neutral to alkaline in reaction, non saline in nature, low to medium in organic carbon (OC) content and cation exchange capacity (CEC). The texture of the soils collected in different villages of Ramannapet, Narkatpalli and Aatmakoor mandals varied as sandy loam, sandy clay and sandy clay loam, respectively (Table 1 and 2). The information regarding contents of available $\mathrm{N}_{2} \mathrm{P}_{2} \mathrm{O}_{5}$ and $\mathrm{K}_{2} \mathrm{O}$ content in both the kharif and rabi seasons were categorized from very low to medium. With respect to available $\mathrm{Zn}, 36(44 \%)$ samples in kharif and $46(56 \%)$ samples in rabi were deficient, while remaining samples were found above critical limit $\left(0.6 \mathrm{mg} \mathrm{kg}^{-1}\right)$ of available $\mathrm{Zn}$. The results on available Fe revealed that, $44 \%$ samples in kharif and $27 \%$ samples in rabi were below critical limit $\left(<4.5 \mathrm{mg} \mathrm{kg}^{-1}\right)$ of available $\mathrm{Fe}$. The available $\mathrm{Mn}, \mathrm{Cu}$ content of soils in both the kharif and rabi seasons are found to be above critical limit. Considering the critical limit for available B as $0.45 \mathrm{mg} \mathrm{kg}^{-1}$, about $75 \%$ samples in kharif and about $32 \%$ samples in rabi were found to be deficient. The results revealed that, all the heavy metals viz., $\mathrm{Cd}, \mathrm{Cr}, \mathrm{Ni}, \mathrm{Pb}$ and $\mathrm{Co}$ analyzed during kharif and rabi seasons were within the permissible limits.

Table 1. Range and mean values of physico-chemical and chemical characteristics of the soil samples collected from different mandals of Nalgonda district (Kharif-2012).

\begin{tabular}{|c|c|c|c|c|c|c|}
\hline \multirow[t]{2}{*}{ Characteristics } & \multicolumn{2}{|c|}{ Ramannapet } & \multicolumn{2}{|l|}{ Narkatpalli } & \multicolumn{2}{|l|}{ Aatmakoor } \\
\hline & Range & Mean & Range & Mean & Range & Mean \\
\hline Sand $(\%)$ & $46.0-66.6$ & 56.8 & $44.0-70.8$ & 57.0 & $47.5-68.5$ & 55.7 \\
\hline Silt (\%) & $7.4-20.5$ & 13.1 & $7.5-17.8$ & 12.3 & $8.2-22.5$ & 14.3 \\
\hline Clay (\%) & $19.8-41.4$ & 30.1 & $12.8-41.4$ & 30.8 & $11.2-40.8$ & 30.0 \\
\hline pH & $7.14-8.64$ & 7.97 & $7.25-8.52$ & 7.76 & $6.98-8.52$ & 7.77 \\
\hline E.C $\left(\mathrm{dS} \mathrm{m}^{-1}\right)$ & $0.14-0.29$ & 0.21 & $0.12-0.32$ & 0.20 & $0.11-0.32$ & 0.21 \\
\hline $\operatorname{CEC~}\left(\mathrm{c} \mathrm{mol}\left(\mathrm{p}^{+}\right) \mathrm{kg}^{-1}\right)$ & $9.86-22.31$ & 15.18 & $8.98-24.64$ & 15.32 & $9.25-21.23$ & 15.40 \\
\hline OC (\%) & $0.23-1.04$ & 0.50 & $0.27-0.70$ & 0.48 & $0.24-0.65$ & 0.40 \\
\hline $\mathbf{N}\left(\mathrm{kg} \mathrm{ha}^{-1}\right)$ & $110-289$ & 191 & $144-296$ & 203 & $116-278$ & 189 \\
\hline $\mathrm{P}_{2} \mathrm{O}_{5}\left(\mathrm{~kg} \mathrm{ha}^{-1}\right)$ & $8.55-32.12$ & 19.49 & $9.36-25.36$ & 19.50 & $8.26-35.21$ & 20.55 \\
\hline $\mathrm{K}_{2} \mathrm{O}\left(\mathrm{kg} \mathrm{ha}^{-1}\right)$ & $125-312$ & 229 & $158-325$ & 255 & $160-320$ & 248 \\
\hline $\mathrm{S}\left(\mathrm{mg} \mathrm{kg}^{-1}\right)$ & $5.78-28.21$ & 12.73 & $5.98-25.56$ & 13.23 & $5.58-23.4$ & 11.30 \\
\hline
\end{tabular}




\begin{tabular}{|c|c|c|c|c|c|c|}
\hline Available F (ppm) & $0.41-2.32$ & 1.17 & $0.26-2.64$ & 1.18 & $0.29-2.02$ & 1.04 \\
\hline Total F (ppm) & $178-451$ & 279 & $195-481$ & 310 & $128-456$ & 291 \\
\hline $\mathrm{Zn}\left(\mathrm{mg} \mathrm{kg}^{-1}\right)$ & $0.23-2.17$ & 0.68 & $0.22-2.02$ & 0.84 & $0.17-6.58$ & 1.06 \\
\hline $\operatorname{Mn}\left(\mathrm{mg} \mathrm{kg}^{-1}\right)$ & $2.56-17.68$ & 8.39 & $2.42-14.56$ & 8.18 & $2.09-21.04$ & 8.48 \\
\hline Fe $\left(\mathrm{mg} \mathrm{kg}^{-1}\right)$ & $2.52-13.56$ & 6.99 & $2.02-18.69$ & 8.28 & $1.98-23.78$ & 7.08 \\
\hline $\mathrm{Cu}\left(\mathrm{mg} \mathrm{kg}^{-1}\right)$ & $0.24-2.99$ & 1.06 & $0.24-3.12$ & 1.13 & $0.34-2.58$ & 1.10 \\
\hline B $\left(\mathrm{mg} \mathrm{kg}^{-1}\right)$ & $0.18-0.89$ & 0.53 & $0.22-1.23$ & 0.64 & $0.18-1.18$ & 0.51 \\
\hline Cd $\left(\mathrm{mg} \mathrm{kg}^{-1}\right)$ & $0-0.21$ & 0.05 & $0-0.24$ & 0.07 & $0-0.32$ & 0.09 \\
\hline $\mathrm{Cr}\left(\mathrm{mg} \mathrm{kg}^{-1}\right)$ & $0-0.18$ & 0.03 & $0-0.09$ & 0.02 & $0-0.08$ & 0.02 \\
\hline $\mathrm{Ni}\left(\mathrm{mg} \mathrm{kg}^{-1}\right)$ & $0.02-0.32$ & 0.20 & $0.09-0.38$ & 0.20 & $0.08-0.45$ & 0.20 \\
\hline $\mathrm{Pb}\left(\mathrm{mg} \mathrm{kg}^{-1}\right)$ & $0.25-1.4$ & 0.71 & $0-1.44$ & 0.42 & $0.08-0.89$ & 0.39 \\
\hline Co $\left(\mathrm{mg} \mathrm{kg}^{-1}\right)$ & $0.02-1.28$ & 0.28 & $0.07-1.2$ & 0.49 & $0.05-1.28$ & 0.43 \\
\hline
\end{tabular}

Table 2. Range and mean values of physico-chemical and chemical characteristics of the soil samples collected from different mandals of Nalgonda district (Rabi 2012-13).

\begin{tabular}{|c|c|c|c|c|c|c|}
\hline \multirow[t]{2}{*}{ Characteristics } & \multicolumn{2}{|l|}{ Ramannapet } & \multicolumn{2}{|l|}{ Narkatpalli } & \multicolumn{2}{|l|}{ Aatmakoor } \\
\hline & Range & Mean & Range & Mean & Range & Mean \\
\hline pH & $7.18-8.65$ & 8.08 & $7.26-8.66$ & 7.95 & $7.20-8.64$ & 7.97 \\
\hline E.C $\left(d_{\left.S ~ ~ m^{-1}\right)}\right.$ & $0.15-0.98$ & 0.49 & $0.14-0.62$ & 0.30 & $0.19-0.81$ & 0.39 \\
\hline $\mathrm{OC}(\%)$ & $0.23-0.71$ & 0.47 & $0.25-0.70$ & 0.46 & $0.16-0.65$ & 0.39 \\
\hline $\operatorname{CEC~}\left(c \operatorname{mol}\left(p^{+}\right) k^{-1}\right)$ & $7.82-21.58$ & 13.45 & $8.52-23.86$ & 14.15 & $6.58-16.58$ & 13.60 \\
\hline $\mathbf{N}\left(\mathrm{kg} \mathrm{ha}^{-1}\right)$ & $153-364$ & 218 & $159-314$ & 215 & $156-314$ & 216 \\
\hline $\mathrm{P}_{2} \mathrm{O}_{5}\left(\mathrm{~kg} \mathrm{ha}^{-1}\right)$ & $12.21-32.65$ & 21.86 & $8.03-35.42$ & 16.86 & $8.66-21.53$ & 13.84 \\
\hline $\mathrm{K}_{2} \mathrm{O}\left(\mathrm{kg} \mathrm{ha}^{-1}\right)$ & $171-312$ & 260 & $159-325$ & 254 & $185-348$ & 263 \\
\hline $\mathrm{S}\left(\mathrm{mg} \mathrm{kg}^{-1}\right)$ & $4.58-34.00$ & 11.39 & $5.50-29.50$ & 10.99 & $6.50-23.65$ & 12.41 \\
\hline Available F (ppm) & $0.77-2.39$ & 1.41 & $0.53-2.64$ & 1.66 & $0.68-2.63$ & 1.54 \\
\hline Total F (ppm) & $186-456$ & 289 & $246-485$ & 338 & $164-458$ & 314 \\
\hline $\mathrm{Zn}\left(\mathrm{mg} \mathrm{kg}{ }^{-1}\right)$ & $0.24-2.14$ & 0.66 & $0.29-1.25$ & 0.70 & $0.27-1.60$ & 0.67 \\
\hline $\operatorname{Mn}\left(\mathrm{mg} \mathrm{kg}^{-1}\right)$ & $2.61-29.55$ & 8.62 & $4.02-39.72$ & 12.63 & $1.35-26.88$ & 9.52 \\
\hline $\mathrm{Fe}\left(\mathrm{mg} \mathrm{kg}^{-1}\right)$ & $2.22-25.23$ & 8.58 & $2.53-16.08$ & 7.84 & $2.82-16.20$ & 8.71 \\
\hline $\mathrm{Cu}\left(\mathrm{mg} \mathrm{kg}^{-1}\right)$ & $0.18-2.71$ & 0.82 & $0.18-1.44$ & 0.73 & $0.16-1.53$ & 0.64 \\
\hline B $\left(\mathrm{mg} \mathrm{kg}^{-1}\right)$ & $0.35-0.55$ & 0.42 & $0.12-0.75$ & 0.36 & $0.15-0.61$ & 0.30 \\
\hline $\mathrm{Cd}\left(\mathrm{mg} \mathrm{kg}^{-1}\right)$ & $0-0.47$ & 0.07 & $0-0.32$ & 0.04 & $0-0.12$ & 0.03 \\
\hline $\mathrm{Cr}\left(\mathrm{mg} \mathrm{kg}^{-1}\right)$ & $0-0.3$ & 0.09 & $0-0.89$ & 0.20 & $0-0.75$ & 0.22 \\
\hline $\mathrm{Ni}\left(\mathrm{mg} \mathrm{kg}^{-1}\right)$ & $0.24-1.2$ & 0.71 & $0.04-1.23$ & 0.45 & $0.25-2.57$ & 0.95 \\
\hline $\mathrm{Pb}\left(\mathrm{mg} \mathrm{kg}{ }^{-1}\right)$ & $0.24-3.01$ & 1.12 & $0.12-1.25$ & 0.64 & $0.28-6.24$ & 3.07 \\
\hline $\mathrm{Co}\left(\mathrm{mg} \mathrm{kg}^{-1}\right)$ & $0.12-1.02$ & 0.35 & $0.12-0.65$ & 0.30 & $0.15-1.21$ & 0.48 \\
\hline
\end{tabular}

\subsection{Correlation between Fluoride Content and Other Constituents of Soil}

Simple correlation co-efficient have been worked out between the available (water soluble) fluoride and other properties of soils. The ' $r$ ' values are presented in the Table 3 . The positive correlation of available fluoride with soil $\mathrm{pH}$, suggesting that the $\mathrm{pH}$ of the soil is more important in determining the concentration of fluoride, in agreement with earlier observation made by Blagojevic et al. (2002).

The available fluoride concentration in soils negatively correlated with EC, CEC and $\mathrm{P}_{2} \mathrm{O}_{5}$ content of soil whereas the correlation coefficient between fluoride and other ions is very poor during both seasons. Increasing fluoride content in soil decreases the available $\mathrm{P}_{2} \mathrm{O}_{5}$ content of the soil. The reduction of $\mathrm{P}_{2} \mathrm{O}_{5}$ content in soil due to $\mathrm{F}$ addition can be attributed to formation of insoluble phosphorus compounds in the soils. Positive correlation coefficients between available fluoride and the content of some micronutrients metals $(\mathrm{Cu}, \mathrm{Mn}$ and $\mathrm{Zn}$ ) were also found, which indicated their mutual geochemical origin. Similar results reported by Jakovljevic et al, (2002).

The relationship between available fluoride and total fluoride was positive but no significant correlation was observed. The available fluoride content was very low $\left(<3 \mathrm{mg} \mathrm{kg}^{-1}\right)$, being mostly less than $2 \%$ from its total amount, so it could be concluded that there was no danger from fluorine accumulation in the plants. Statistically significant correlation coefficient between total and available fluorine contents was not obtained. Similar results reported by Jakovljevic et al, (2002).

It is interesting to note that, fluoride is negatively correlated with clay percent of soils and positively correlated with sand percent of soils during both seasons but no significant correlation was observed. Clay, soil $\mathrm{pH}$ and $\mathrm{P}_{2} \mathrm{O}_{5}$ in soil control fluoride content in the soil solution. Most of the fluoride in the soil is insoluble and, therefore, less available to plants. However, high soil fluoride concentrations or clay can increase fluoride levels in soil solution, increasing uptake via the plant root. 
Table 3: Correlation coefficients (r) between available fluoride content and other chemical constituents of soils

\begin{tabular}{|c|c|c|c|c|c|c|c|}
\hline \multirow{3}{*}{$\begin{array}{l}\text { S. } \\
\text { No }\end{array}$} & \multirow{3}{*}{ Correlation Among } & \multicolumn{6}{|c|}{$\mathbf{r}$ value in } \\
\hline & & \multicolumn{2}{|c|}{ Ramannapet } & \multicolumn{2}{|c|}{ Narkatpalli } & \multicolumn{2}{|c|}{ Aatmakoor } \\
\hline & & Khari & Rabi & Kharif & Rabi & Kharif & Rabi \\
\hline 1 & Available Fluoride vs pH & $* * 0.68$ & $* 0.382$ & $* 0.398$ & $* 0.464$ & $* 0.451$ & $* 0.439$ \\
\hline 2 & Available Fluoride vs EC & -0.289 & -0.105 & -0.259 & -0.213 & -0.140 & -0.032 \\
\hline 3 & Available Fluoride vs CEC & -0.415 & -0.241 & -0.353 & -0.384 & -0.525 & -0.353 \\
\hline 4 & Available Fluoride vs Available $\mathrm{P}_{2} \mathrm{O}_{5}$ & -0.394 & -0.423 & -0.562 & -0.694 & -0.366 & -0.407 \\
\hline 5 & Available Fluoride vs Available $\mathrm{K}_{2} \mathrm{O}$ & -0.014 & 0.101 & 0.074 & 0.041 & 0.019 & -0.077 \\
\hline 6 & Available Fluoride vs Available $\mathrm{Cu}$ & -0.046 & 0.056 & -0.020 & 0.164 & 0.336 & 0.265 \\
\hline 7 & Available Fluoride vs Available Mn & 0.049 & -0.029 & 0.202 & 0.186 & -0.105 & 0.131 \\
\hline 8 & Available Fluoride vs Available Iron & -0.167 & -0.108 & -0.033 & -0.091 & 0.089 & -0.256 \\
\hline 9 & Available Fluoride vs Available Zinc & -0.049 & -0.122 & -0.157 & -0.039 & 0.177 & 0.111 \\
\hline 10 & Available Fluoride vs Total fluoride & 0.276 & 0.349 & 0.340 & 0.271 & 0.381 & 0.253 \\
\hline & & \multicolumn{6}{|c|}{$* 5 \%(0.389)$} \\
\hline & & \multicolumn{6}{|c|}{$* * 1 \%(0.499)$} \\
\hline
\end{tabular}

\section{Conclusions}

A significant positive correlation coefficient (r) values were observed between fluoride and $\mathrm{pH}$, while fluoride was negatively related with soluble salt content. Soil with low clay and $\mathrm{P}_{2} \mathrm{O}_{5}$ favors greater solubilization of the fluoride bearing minerals leads to leaching of fluoride which results increase in the concentration of soil fluoride. Clay, soil $\mathrm{pH}$ and $\mathrm{P}_{2} \mathrm{O}_{5}$ in soil control fluoride content in the soil solution.

\section{Acknowledgement}

The authors are grateful to Professor Jayashankar Telangana State Agricultural University for providing financial assistance during my post-graduation under Dept. of Soil Science \& Agricultural Chemistry, College of Agriculture, Rajendranagar, Hyderabad during the study.

\section{References}

[1]. Rakshit, P.K, Studies on Estimation of Fluoride and Defluoridation of Drinking Water, Thesis, India Institute of Science, Bangalore, 2004.

[2]. Wedepohl, K. H.. Handbook of geochemistry (Vol. II-1, Berlin, Springer, 1969).

[3]. Rao, N.V.R., Rao, K.S and Schuilding, R.D, Fluorine distribution in waters of Nalgonda District, Andhra Pradesh, India, Environmental Geology, 21, 1993, 84-89.

[4]. Reddy, D.V., Nagabhushanam, P., Sukhija, B.S., Reddy, A.G.S and Smedley, P.L., Fluoride dynamics in the granitic aquifer of the Wailapally watershed, Nalgonda district, India. Journal of Hydrology, 592, 2009, 7236.

[5]. Omueti, J.A.I. and Jones, R.L. Fluoride adsorption by Illinois soils, Journal of Soil Science, 28, 1977, 564-572.

[6]. Jackson, M.L., Soil Chemical Analysis, (Printice Hall of India Private Limited, New Delhi, 1973).

[7]. Subbiah, B.V. and Asija, G.L., A rapid procedure of the estimation of available nitrogen in soils, Current Science, 25, 1956, 259260.

[8]. Olsen, S.R., Cole, C.V., Watanabe, F.S and Dean, L.A., Estimation of available phosphorus in soils by extraction with sodium bicarbonate, (US Department of Agriculture Circular, 1954).

[9]. Watanabe F.S. and Olsen S.R, Test for ascorbic acid method for determining phosphorus in water and sodium bicarbonate extracts of soil. Soil Science Society of America Proceedings, 29, 1965, 677-678.

[10]. Lindsay, W.L. and Norvell, W.A., Development of a DTPA soil test for zinc, iron, manganese and copper, Soil Science Society of America Journal, 42, 1978, 421-428.

[11]. McQuaker, N, and Gurney, M, Determination of total fluoride in soil and vegetation using an alkali fusion selective ion electrode technique, Analytical Chemistry, 49, 1977, 53-56.

[12]. WHO, Fluorine and fluorides, (Environmental Health Criteria Geneva 36, 1984).

[13]. Davidson, A, The effects of fluoride on plant growth and forage quality in effect of gaseous air pollution in agriculture and horticulture, (Ormord, London butter worth, 1983).

[14]. Okibe, F.G., Ekanem, E.J., Paul, E.D., Shallangwa, G.A., Ekwumemgbo, P.A., Sallau, M.S. and Abanka, O.C., Fluoride content of soil and vegetables from irrigation farms on the bank of river Galma, Zaria, Nigeria, Australian Journal of Basic and Applied Sciences, 4(5), 2010, 779-784.

[15]. Newman., J.R, Fluoride standards and predicting wildlife effects, Journal of the International Society for Fluoride Research, 17, 1984, 41-47.

[16]. Jakovljevic, M., Blagojevic, S. and Mladenovic, S.A, Fluorine content in soils of Northern Pomoravlje, Journal of Agricultural Sciences, 47(2), 2002, 121-128.

[17]. Blagojevic, S., Jakovljevic, M. and Radulovic, M, Content of fluorine in soils in the vicinity of aluminium plant in Podgorica, Journal of Agricultural Sciences, 47(1), 2002, 1-8. 